\title{
Dairy cow production when supplemented with whole-crop cereal silages in spring and autumn
}

\author{
D.R. STEVENS ${ }^{1}$, G.J. PLATFOOT ${ }^{2}$, M.G. HYSLOP ${ }^{3}$, T.L. KNIGHT ${ }^{3}$, I.D. CORSON ${ }^{1}$ and R.J. LITTLEJOHN ${ }^{1}$ \\ ${ }^{1}$ AgResearch, Invermay Agricultural Centre, PB 50034, Mosgiel \\ ${ }^{2}$ Platfoot Enterprises Ltd, R.D. 2, Invercargill \\ ${ }^{3}$ AgResearch, Canterbury Agriculture and Science Centre, P.O. Box 60, Lincoln \\ david.stevens@agresearch.co.nz.
}

\begin{abstract}
The on-farm milk production, pasture intake and silage intake of cows fed either whole-crop cereal silage or pasture silage as a supplement to pasture was compared in four herds in autumn and two herds in spring during 2002 and 2003. The number of cows per herd ranged from 90 to 270 cows per feeding treatment. Silages were supplemented at rates determined by farmer feed budget. The amount offered ranged from 3 to $6.6 \mathrm{~kg} \mathrm{DM} / \mathrm{cow} /$ day. Pasture intake estimates ranged from 7.2 to $13.0 \mathrm{~kg}$ $\mathrm{DM} /$ cow/day. Milksolids (MS) production ranged from 0.93 to $1.61 \mathrm{~kg} / \mathrm{cow} /$ day in autumn and from 1.33 to $1.98 \mathrm{~kg} / \mathrm{cow}$ in spring. The feeding of whole-crop cereal silage produced more MS production in two autumn studies compared to feeding pasture silage as a supplement $(+0.08 \mathrm{~kg} / \mathrm{cow} / \mathrm{d} ; \mathrm{P}<0.001)$. Feeding pasture silage produced more MS production in one spring study compared to feeding whole-crop cereal silage as a supplement $(+0.06 \mathrm{~kg} /$ cow/day; $\mathrm{P}<0.01)$. Variations in feed intake and feed nutrient concentrations were the major reasons for variation in milk production changes. The feed quality of whole-crop cereal silages was more variable than pasture silages and low quality was reflected in some palatability and acceptance problems with wholecrop cereal silage. Whole-crop cereal silages fed in 2003 were of more consistent and higher quality than those fed in 2002. Cow live weight gain and body condition score changes reflected the feed intake and feed quality offered to the cows. Whole-crop cereal silages showed potential to equal or better the production gained from supplementing pasture silage when the amount fed was equal and when whole-crop cereal silage quality was high.
\end{abstract}

Keywords: dairy cows, feed intake, feed nutrient concentration, milk constituents, milk production, pasture, pasture silage, whole-crop cereal silage

\section{Introduction}

Whole-crop cereal silage is an exciting area of potential integration of the cropping and dairy industries. It provides dairy farmers with an opportunity to source a large amount of feed from an outside contractor who is skilled in growing the crop. Cropping farmers would also benefit by having an extra product option within the cropping system with the potential to provide a grazeable winter feed and a saleable summer crop (de Ruiter et al. 2002).

The use of whole-crop cereal silage as a forage for dairy cows provides several advantages. Whole-crop cereals such as wheat, barley or triticale offer high quality forage in regions where maize silage is limited by growing season or out of season frosts. Large quantities of cereal forage can be grown either on-farm or oncontract. Other benefits include the opportunities for the arable industry to supply the dairy industry and the dairy industry to gain the benefits of cereal growing expertise without having to invest in land, capital or expertise.

Of particular importance to dairy farmers is the cow response to whole-crop cereal silage. Is whole-crop cereal silage a substitute for pasture silage or is it something more? International research has concentrated on using whole-crop cereal silages as a substitute for pasture or maize silages in essentially concentrate diets for lactating cows (Khorasani et al. 1993; Kristensen 1992; Phipps et al. 1992) or finishing cattle (Leaver \& Hill 1992; O'Kiely \& Moloney 1995; Tetlow \& Wilkinson 1992). However, knowledge is lacking on the production benefits of whole-crop cereal silage fed as a supplement to pasture in New Zealand dairy systems. Until these benefits are clearly shown, the integration of whole-crop cereal silage will be slow.

An on-farm demonstration project evaluated the milk production of dairy herds fed a supplement of either pasture silage or whole-crop cereal silage during either spring or autumn in 2002 and 2003. A further study compared whole-crop cereal silage to pasture silage supplementation at pasture in autumn 2003. This paper documents the range of production from whole-crop cereal silage supplementation and evaluates the effectiveness of whole-crop cereal silage as an alternative to pasture silage.

\section{Materials and methods}

The project included dairy herds in early lactation (September and October 2002 and 2003) and late lactation (March, April and May 2002 and 2003). Each herd was randomly split and offered either whole-crop cereal silage or pasture silage as a supplement to pasture. 
A total of four herds in autumn and two herds in spring were measured. Five of the six demonstrations were in West Otago and Southland, New Zealand, an area with a cool temperate climate with mean daily temperatures ranging from $5^{\circ} \mathrm{C}$ in winter to $15^{\circ} \mathrm{C}$ in summer. Rainfall ranges from 750 to $1200 \mathrm{~mm}$, with a summer maximum and little or no soil moisture deficit throughout the year. The final demonstration was in Canterbury, New Zealand, an area with a mild temperate climate with mean daily temperatures ranging from $6^{\circ} \mathrm{C}$ in winter to $17^{\circ} \mathrm{C}$ in summer. Rainfall averages $650 \mathrm{~mm}$, with irrigation required in summer as soil moisture deficits are common.

Milk quantity and constituents were taken approximately weekly by standard herd testing procedures. Live weight and body condition score (BCS; 10 point scale with 1 being low) were monitored at regular intervals on a sample of cows in each herd during autumn 2002, autumn 2003 and spring 2003.

Feed nutrient concentration analysis, including metabolisable energy (ME), soluble sugars and starch, crude protein, neutral detergent fibre (NDF), and acid detergent fibre (ADF) (NIRS analysis, Corson et al. 1999), were measured at regular intervals. Pasture allowance and residual herbage mass (plate meter) were measured weekly. Pasture intakes were calculated from these values. Pasture allowances were determined by the individual farmers according to their feed supply situations. Cows were introduced to the silages and allowed a 10-day period to adjust to the change in diet in each study. Silage allowance was either weighed or estimated from quantities taken from the pit face, with no allowance for refusal or wastage. All silages were fed on the pasture except for the autumn 2003 Canterbury study where silage was fed in troughs with no waste.

\section{Spring demonstrations}

In spring 2002 (Spring 1) a milking herd of 540 Friesian cows in Kelso, West Otago, was split approximately in half and offered $4 \mathrm{~kg} \mathrm{DM} / \mathrm{cow} /$ day of either pasture silage or whole-crop cereal (barley) silage as a supplement to pasture during the spring of 2002 . Measurements were made from 11 September until 20 October 2002. The herd had an average production history of $375 \mathrm{MS} / \mathrm{cow}$, and was stocked at $2.67 \mathrm{cows} /$ ha. Cow live weight was estimated at $540 \mathrm{~kg}$.

In spring 2003 (Spring 2) a herd of 190 mixed breed (Friesian, Jersey and Friesian x Jersey) cows in Otautau, Western Southland, was split into two mobs as they calved and fed a supplement of either pasture silage or whole-crop cereal (triticale) silage during the early lactation period. A varying amount of silage (3.6 to 7.1 $\mathrm{kg} \mathrm{DM} /$ cow/day) was offered as a supplement, depending on pasture availability. Milk production measurements were taken on 5 occasions from 2 September 2003 to 7 October 2003. Pasture and silage intakes were estimated on 4 occasions from 16 September 2003 to 7 October 2003.

\section{Autumn demonstrations}

In autumn 2002 two farms, at Balfour, Northern Southland, and Otautau, Western Southland, were studied. Both farms used whole-crop cereal (barley) silages. The silage supplements were fed at approximately $3 \mathrm{~kg} \mathrm{DM} / \mathrm{cow} /$ day. Pasture allowances were kept similar for each herd.

The Balfour Friesian herd (Autumn 1) was split randomly in early-March into herds of 200 and 207 fed pasture silage or whole-crop cereal silage respectively. All cows were also fed $1 \mathrm{~kg} / \mathrm{d}$ of meal concentrate. Feeding of the silages began on 11 March 2002 and measurements concluded on 10 April 2002.

The Otautau Friesian herd (Autumn 2) had been split randomly within each cow age group in October. The two herds of 216 and 208 were fed either pasture silage or whole-crop cereal silage which began on 3 March 2002 and measurements concluded on 10 April 2002. The cows were grazed separately with average opening covers of 1960 and $1900 \mathrm{~kg} \mathrm{DM} / \mathrm{ha}$ (3 March 2002) and closing covers of 1880 and $1900 \mathrm{~kg} \mathrm{DM} / \mathrm{ha}$ (10 April 2002) for the pasture and whole-crop cereal silage herds respectively.

In autumn 2003 (Autumn 3) a third farm, in Otautau, Western Southland, was studied. The milking herd of 189 cows of mixed breed (Friesian, Jersey and Friesian $\mathrm{x}$ Jersey) was split in half and fed either pasture silage (93 cows) or whole-crop cereal (barley) silage (90 cows). Supplements were fed at approximately $6 \mathrm{~kg}$ $\mathrm{DM} /$ cow/day and measurements were made from 25 March until 15 April 2003.

A final study in autumn 2003 (Autumn 4) was done at Lincoln, Canterbury, comparing pasture silage with whole-crop cereal (triticale) silage fed at $5 \mathrm{~kg} \mathrm{DM} / \mathrm{cow} /$ day. Two groups of twenty Friesian cows were selected from a group of 220 cows and balanced for production and calving date. Each group was break grazed separately, but in the same paddock, and measurements were made from 14 April to 16 May 2003.

Cows were weighed on 15 April 2003 and 19 May 2003. The final weighing was delayed for three days after the completion of the trial to achieve a common gut fill, similar to the conditions at the initial weighing.

Pasture allowances were adjusted daily to achieve an intake of approximately $10 \mathrm{~kg} \mathrm{DM} /$ cow/day. Average pasture covers were $2500 \mathrm{~kg} \mathrm{DM} / \mathrm{ha}$ with a residual herbage mass of approximately $1500 \mathrm{~kg} \mathrm{DM} / \mathrm{ha}$. Pasture covers were measured each day (pre- and postgrazing) using a rising plate meter. Calibration cuts for 
the plate meter were taken at the start, middle and end of the trial ( 20 cuts per time).

\section{Data analysis}

Total milk production (1/cow/day), milksolids (MS) (kg/ cow/day; milk fat plus milk protein), milk fat (\%) and milk protein (\%) were analysed statistically by residual maximum likelihood (Patterson \& Thompson 1971), with the random effects given by date, fixed effects by treatment, age (which was known for all cows) and their interaction plus date, and first-order autoregressive correlation structure for date. Records were analysed after non-sensible measurements were removed. Pasture variables and cow live weight and BCS were analysed using simple t-testing to describe the conditions under which the milk production results occurred.

\section{Results}

\section{Milk production}

Lower total milk yields ( $1 /$ cow/day) were recorded for cows supplemented with whole-crop cereal silage $(\mathrm{P}<0.01)$ than cows supplemented with pasture silage in Spring 2 (Table 1). Total milk yield of cows supplemented with whole-crop cereal silage was higher $(\mathrm{P}<0.05)$ than cows supplemented with pasture silage in Autumn 1 (Table 1).

Milksolids production ( $\mathrm{kg} / \mathrm{cow} /$ day) was greater when whole-crop cereal silage was fed in Autumn 1 and Autumn $2(\mathrm{P}<0.001)$ when compared with feeding pasture silage. Milksolids were lower $(\mathrm{P}<0.01)$ when cows were

Table 1 Total milk yield, MS production and milk fat and milk protein percent from cows fed either pasture silage or whole-crop cereal silage in addition to pasture.

\begin{tabular}{|c|c|c|c|c|c|c|c|}
\hline & \multirow[b]{2}{*}{$\begin{array}{l}\text { Silage feeding } \\
\text { treatment }\end{array}$} & \multirow[b]{2}{*}{ Spring 1} & \multirow[b]{2}{*}{ Spring 2} & \multirow{2}{*}{$\begin{array}{l}\text { Demo } \\
\text { Autumn } 1\end{array}$} & \multirow{2}{*}{$\begin{array}{l}\text { stration } \\
\text { Autumn } 2\end{array}$} & \multirow[b]{2}{*}{ Autumn 3} & \multirow[b]{2}{*}{ Autumn 4} \\
\hline & & & & & & & \\
\hline \multirow{4}{*}{$\begin{array}{l}\text { Milk total } \\
\text { (I/cow/day) }\end{array}$} & Pasture & 25.2 & 16.2 & 14.5 & 16.7 & 8.9 & 19.5 \\
\hline & Whole-crop & 24.7 & 14.9 & 15.2 & 17.3 & 8.9 & 20.1 \\
\hline & SED & 0.43 & 0.47 & 0.31 & 0.39 & 0.33 & 1.22 \\
\hline & & $\mathrm{NS}^{1}$ & $\star *$ & * & NS & NS & NS \\
\hline \multirow{5}{*}{$\begin{array}{l}\text { Milksolids } \\
\text { (kg/cow/day) }\end{array}$} & & & & & & & \\
\hline & Pasture & 1.98 & 1.41 & 1.22 & 1.53 & 0.94 & 1.56 \\
\hline & Whole-crop & 1.92 & 1.33 & 1.31 & 1.61 & 0.93 & 1.56 \\
\hline & SED & 0.027 & 0.038 & 0.022 & 0.026 & 0.027 & 0.064 \\
\hline & & $\star \star$ & NS & 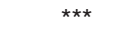 & $\star \star \star$ & NS & NS \\
\hline \multirow[t]{4}{*}{ Milkfat (\%) } & Pasture & 4.34 & 4.65 & 4.68 & 5.11 & 6.15 & 4.59 \\
\hline & Whole-crop & 4.33 & 4.75 & 4.74 & 5.28 & 6.11 & 4.35 \\
\hline & SED & 0.063 & 0.094 & 0.077 & 0.088 & 0.141 & 0.183 \\
\hline & & ns & ns & ns & * & ns & ns \\
\hline \multirow{4}{*}{ Protein (\%) } & Pasture & 3.62 & 4.13 & 3.95 & 4.17 & 4.56 & 3.59 \\
\hline & Whole-crop & 3.55 & 4.28 & 3.96 & 4.22 & 4.59 & 3.61 \\
\hline & SED & 0.032 & 0.052 & 0.034 & 0.042 & 0.070 & 0.108 \\
\hline & & NS & $\star \star * *$ & NS & NS & NS & NS \\
\hline
\end{tabular}

${ }^{1}$ NS not significant; ${ }^{*} \mathrm{P}<0.05 ;{ }^{* *} \mathrm{P}<0.01 ;{ }^{* *} \mathrm{P}<0.001$.

Table 2 Pasture intake and silage offered to dairy cows fed either pasture or whole-crop cereal silage as a supplement.

\begin{tabular}{|c|c|c|c|c|c|c|c|}
\hline & \multirow[b]{2}{*}{$\begin{array}{l}\text { Silage feeding } \\
\text { treatment }\end{array}$} & \multirow[b]{2}{*}{ Spring 1} & \multirow[b]{2}{*}{ Spring 2} & \multirow{2}{*}{$\begin{array}{l}\text { Demo } \\
\text { Autumn } 1\end{array}$} & \multirow{2}{*}{$\begin{array}{l}\text { stration } \\
\text { Autumn } 2\end{array}$} & \multirow[b]{2}{*}{ Autumn 3} & \multirow[b]{2}{*}{ Autumn 4} \\
\hline & & & & & & & \\
\hline \multirow{4}{*}{$\begin{array}{l}\text { Pasture } \\
\text { intake (kg } \\
\text { DM/cow/day) }\end{array}$} & Pasture & 12.3 & 13.0 & 12.2 & 12.2 & 7.6 & 12.4 \\
\hline & Whole-crop & 12.4 & 9.9 & 12.2 & 12.2 & 7.2 & 11.8 \\
\hline & SED & 1.81 & 0.85 & 0.28 & 0.26 & 2.65 & 0.34 \\
\hline & & NS & $\star *$ & NS & NS & NS & NS \\
\hline \multirow{3}{*}{$\begin{array}{l}\text { Silage on } \\
\text { offer (kg } \\
\text { DM/cow/day) }\end{array}$} & Pasture & 4.0 & 5.3 & 3.0 & 3.0 & 6.6 & 5.0 \\
\hline & Whole-crop & 4.0 & 4.5 & 3.0 & 3.0 & 6.0 & 5.0 \\
\hline & SED & $n d^{1}$ & $\begin{array}{c}0.96 \\
\text { NS }\end{array}$ & nd & nd & $\begin{array}{c}0.95 \\
\text { NS }\end{array}$ & $\begin{array}{c}0.25 \\
\text { NS }\end{array}$ \\
\hline
\end{tabular}


Figure 1 Metabolisable energy, soluble sugar and starch and crude protein concentrations, estimated by NIRS, of pasture and silages fed to cows during either spring or autumn (bars indicate SED for pasture or silage comparisons).

a) Metabolisable energy concentration

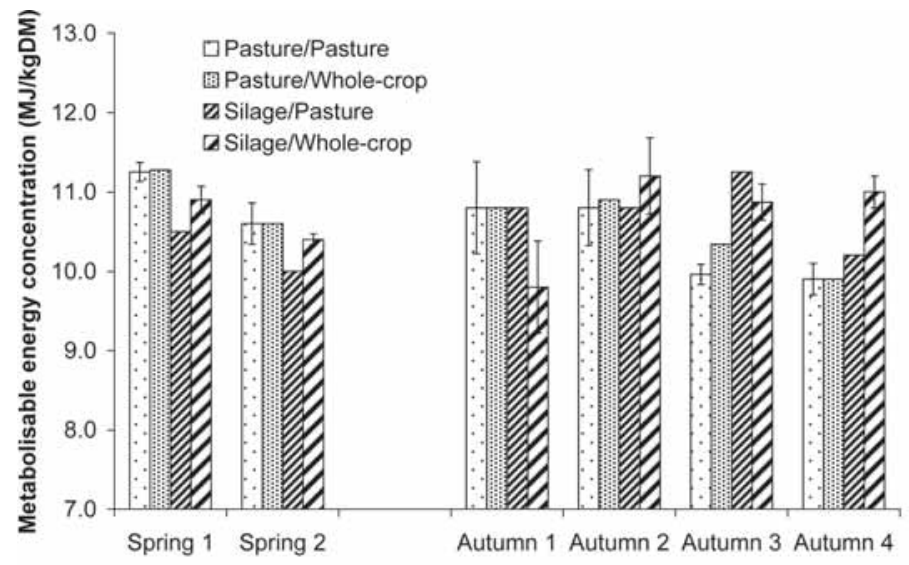

b) Soluble sugars and starch concentration

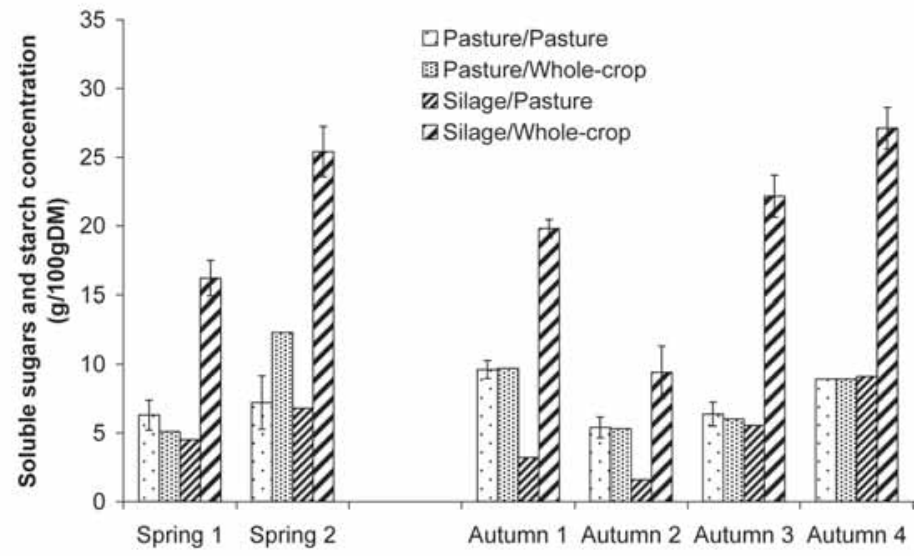

c) Crude protein concentration

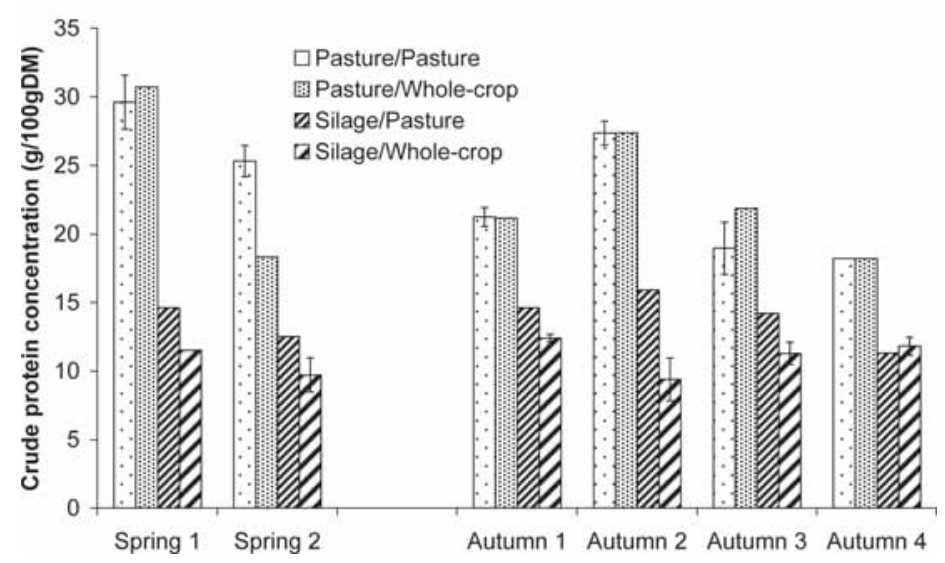


Table 3 Pasture and silage acid detergent fibre (ADF) and neutral detergent fibre (NDF) concentrations of forages fed to dairy cows, measured by near infrared spectrophotometery (NIRS).

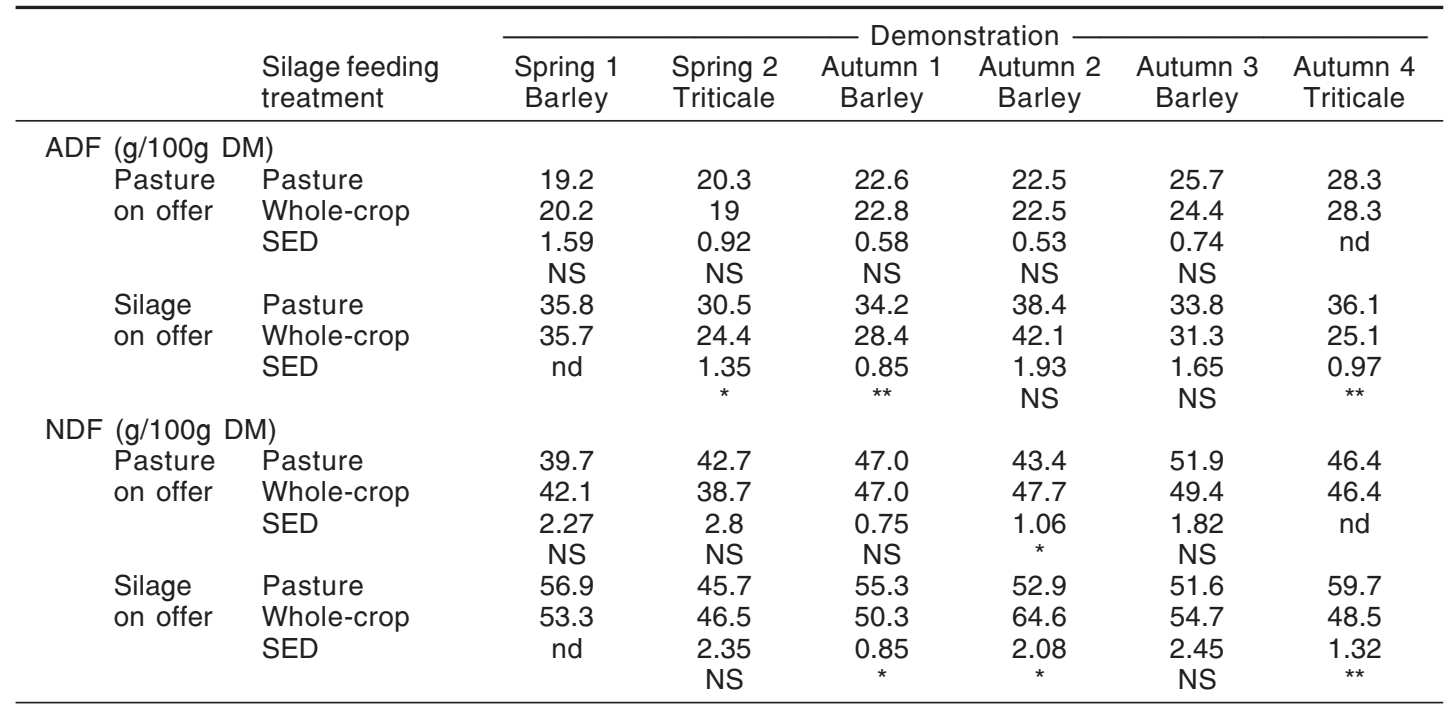

1 no data

${ }^{2}$ NS not significant, ${ }^{*} \mathrm{P}<0.05,{ }^{* *} \mathrm{P}<0.01$

supplemented with whole-crop cereal silage in Spring 1 compared to cows supplemented with pasture silage.

Some variations in both milk fat and milk protein concentrations were recorded (Table 1) but were small.

\section{Feed intake}

Pasture intakes and silage on offer (Table 2) to cows fed pasture silage or whole-crop cereal silage were relatively similar except Spring 2 where pasture intake was higher for cows supplemented with pasture silage than those supplemented with whole-crop cereal silage $(\mathrm{P}<0.01)$.

\section{Feed nutrient concentrations}

Metabolisable energy concentration (Figure 1) of the pastures offered to the cows was similar in each demonstration except for Autumn 3 when the pasture fed to cows supplemented with pasture silage was lower than that fed to cows supplemented with whole-crop cereal silage. The ME concentration of the whole-crop cereal silage was higher than that of the pasture silage in both spring demonstrations and in Autumn 4. The ME concentration of the pasture or whole-crop cereal silages fed in the Autumn 1, 2 and 3 demonstrations were not significantly different.

The soluble sugars and starch concentration (Figure 1) of the pastures fed to cows supplemented with pasture silage were lower than those pastures fed to whole-crop cereal silage supplemented cows in the Spring 2 demonstration $(\mathrm{P}=0.057)$. Soluble sugars and starch concentrations were similar in pastures fed to either pasture silage or whole-crop cereal silage supplemented cows. The soluble sugars and starch concentration of whole-crop cereal silages were always significantly greater than those of pasture silages (Figure 1).

Crude protein concentrations of pastures fed to cows supplemented with whole-crop cereal silage during Spring 2 were lower than $(\mathrm{P}<0.05)$ pastures fed to cows supplemented with pasture silage. Pasture silage had higher crude protein concentrations than whole-crop cereal silage in all but the Autumn 4 demonstration $(\mathrm{P}<0.05)$.

The ADF concentrations of pastures fed to cows supplemented with pasture and whole-crop cereal silage were not significantly different in each demonstration (Table 3). The NDF concentrations of pastures fed to cows supplemented with pasture and whole-crop cereal silage were significantly different in the Autumn 2 demonstration (Table 3 ). The pasture silages had higher ADF concentrations than the whole-crop cereal silages in Spring 2, Autumn 1 and Autumn 4 (Table 3, $\mathrm{P}<0.05$ ). The NDF concentrations were higher in the pasture silages in Autumn 1 and Autumn 4, while the wholecrop cereal silage had a higher NDF concentration in Autumn 2 (Table 3).

Silage $\mathrm{pH}$ values ranged between 3.7 and 5.0, though were not significantly different in any one study $(\mathrm{P}>0.05)$.

\section{Live weight and BCS}

Cow liveweight change (Table 4) was similar when fed either pasture silage or whole-crop cereal silage as a supplement in both spring and autumn. Body condition 
Table 4 Initial live weights, liveweight gains, body condition score and body condition score change measured or observed in cows supplemented with either pasture silage or whole-crop cereal silage.

\begin{tabular}{|c|c|c|c|c|c|c|c|}
\hline & \multirow[b]{2}{*}{$\begin{array}{l}\text { Silage feeding } \\
\text { treatment }\end{array}$} & \multirow[b]{2}{*}{ Spring $1^{1}$} & \multirow[b]{2}{*}{ Spring 2} & \multicolumn{2}{|c|}{ Demonstration } & \multirow[b]{2}{*}{ Autumn 3} & \multirow[b]{2}{*}{ Autumn 4} \\
\hline & & & & Autumn 1 & Autumn 2 & & \\
\hline $\begin{array}{l}\text { Initial live } \\
\text { weight (kg)) }\end{array}$ & $\begin{array}{l}\text { Pasture } \\
\text { Whole-crop } \\
\text { SED }\end{array}$ & $\begin{array}{l}\mathrm{nd}^{2} \\
\mathrm{nd}\end{array}$ & $\begin{array}{l}391 \\
355 \\
41.3 \\
\mathrm{NS}^{3}\end{array}$ & $\begin{array}{r}511 \\
517 \\
47.9 \\
\text { NS }\end{array}$ & $\begin{array}{c}508 \\
520 \\
30.3 \\
\text { NS }\end{array}$ & $\begin{array}{c}437 \\
446 \\
38.8 \\
\text { NS }\end{array}$ & $\begin{array}{c}602 \\
585 \\
34.5 \\
\text { NS }\end{array}$ \\
\hline $\begin{array}{l}\text { Liveweight } \\
\text { change }(\mathrm{kg})\end{array}$ & $\begin{array}{l}\text { Pasture } \\
\text { Whole-crop } \\
\text { SED }\end{array}$ & $\begin{array}{l}\text { nd } \\
\text { nd }\end{array}$ & $\begin{array}{c}19.5 \\
28.6 \\
5.3 \\
\text { NS }\end{array}$ & $\begin{array}{c}21.4 \\
3.8 \\
11.2 \\
\text { NS }\end{array}$ & $\begin{array}{c}7 \\
1 \\
\text { nd }\end{array}$ & $\begin{array}{c}0.8 \\
-5.9 \\
4.27 \\
\text { NS }\end{array}$ & $\begin{array}{c}24.0 \\
18.0 \\
5.4 \\
\text { NS }\end{array}$ \\
\hline $\begin{array}{l}\text { Initial body } \\
\text { condition } \\
\text { score }(1-10)\end{array}$ & $\begin{array}{l}\text { Pasture } \\
\text { Whole-crop } \\
\text { SED }\end{array}$ & $\begin{array}{l}4.5 \\
4.5 \\
\text { nd }\end{array}$ & $\begin{array}{c}4.3 \\
4.5 \\
0.19 \\
\text { NS }\end{array}$ & $\begin{array}{l}\text { nd } \\
\text { nd }\end{array}$ & $\begin{array}{l}\text { nd } \\
\text { nd }\end{array}$ & $\begin{array}{c}4.5 \\
4.9 \\
0.42 \\
\text { NS }\end{array}$ & $\begin{array}{l}\text { nd } \\
\text { nd }\end{array}$ \\
\hline $\begin{array}{l}\text { Body condition } \\
\text { score change }\end{array}$ & $\begin{array}{l}\text { Pasture } \\
\text { Whole-crop } \\
\text { SED }\end{array}$ & $\begin{array}{c}0.25 \\
0.00 \\
\text { nd }\end{array}$ & $\begin{array}{l}0.43 \\
0.20 \\
0.28 \\
\text { NS }\end{array}$ & $\begin{array}{l}\text { nd } \\
\text { nd }\end{array}$ & $\begin{array}{l}\text { nd } \\
\text { nd }\end{array}$ & $\begin{array}{c}0.30 \\
-0.30 \\
0.16 \\
*\end{array}$ & $\begin{array}{l}\text { nd } \\
\text { nd }\end{array}$ \\
\hline
\end{tabular}

score was also relatively unaffected by the type of silage supplement except for a significant decline $(\mathrm{P}<0.05)$ in body condition measured in Autumn 3.

\section{Discussion}

Supplementation with whole-crop cereal silage produced the best results in autumn with significant increases in MS production in both Autumn 1 and Autumn 2. Intake estimates for Autumn 3 suggested a difference of approximately $1 \mathrm{~kg} \mathrm{DM} / \mathrm{cow} /$ day in favour of the pasture silage treatment. This was equivalent to approximately $10 \mathrm{MJME} / \mathrm{d}$ which would, if fed, have increased potential milk yield by approximately 0.15 to $0.17 \mathrm{~kg} \mathrm{MS} /$ day, as predicted by the National Research Council Nutrient requirements of dairy cattle model (NRC 2001). This would provide a production increase in line with those gained in the previous two autumn studies.

Cows in the Autumn 4 study had similar intakes and produced very similar amounts of milk when fed either pasture silage or whole-crop cereal silage, despite the whole-crop cereal silage having a significantly higher ME than the pasture silage or the pastures fed. Both diets had an average protein concentration of $16.2 \%$. Estimates of milk production from the NRC requirements of dairy cattle model (NRC 2001) using the measured parameters indicated that these diets were marginally protein deficient.

Higher MS production from cows supplemented with pasture silage in Spring 1 may have been due to the marked aversion to the whole-crop cereal silage at its introduction and throughout the study. Therefore the amount of silage on offer in Spring 1 was not a good indicator of silage intake. The small decrease in MS production from cows fed whole-crop cereal silage may have resulted from the lower total intake of feed. Silage quality parameters such as $\mathrm{pH}(3.7)$ and $\mathrm{NH}_{4} \mathrm{~N}(6 \%)$ did not indicate any problems with the silage, though the combination of low $\mathrm{pH}$ and high NDF concentrations along with relatively low soluble sugars and starch may have made the whole-crop cereal silage less appealing than the pasture available. The cow condition loss with the use of the whole-crop cereal silage supplement may have also been due to lower intakes.

Cows fed the whole-crop cereal silage in Spring 2 produced significantly less total milk but MS production was similar when compared to the cow fed the pasture silage treatment. The NRC Nutrient requirements of dairy cattle model (NRC 2001) was used to calculate the theoretical intakes required to achieve the production recorded. These theoretical intakes confirmed that the measured milk production and BCS change were consistent with the estimated intakes from cow supplemented with whole-crop cereal silage but the live weight gain of cows fed the whole cereal silage was greater than that modelled using the recorded feed intake. This suggests that either the feeding value of the cereal silage may have indeed been higher than that estimated or pasture intakes were higher than those seen on the measurement days. The low protein concentration of the diet may explain the liveweight gain of the cows 
without a corresponding increase in milk production. The predicted energy intake was high enough for gain even though the protein intake was not great enough for milk production (NRC 2001). This result highlights the importance of testing both the pasture and the supplementary feed to ensure that nutritional requirements are fully met.

The same herd was used in the Spring 2 and Autumn 3 demonstrations. This herd was of smaller body weight and lower production than the other herds, and was a cross-bred herd, rather than a Friesian herd. Some genetic and age variations will have contributed to the lower average production from this herd.

The pasture silage crops being fed had relatively high nutrient concentrations compared to the average made in New Zealand (Platfoot \& Stevens 2002). The nutrient concentrations of whole-crop cereal silages were more variable. The low soluble sugars and starch, low protein and high ADF and NDF concentrations of the wholecrop cereal silages in Spring 1 and Autumn 2 are indicative of late harvesting of the barley crop with significant grain loss, and may explain the low palatability reported by the farmers in these two studies. Surprisingly however, an increase in milk production was still gained from the Autumn 2 study. This increase was thought to be due to a combination of balancing fibre and protein in a pasture diet that contained very high protein concentrations and low dry matter content as a result of fertiliser nitrogen application in the Autumn 2 study. Silage quality may be improved by more attention to harvest time and ensiling procedures. Fewer problems in later trials may indicate that farmers and contractors are improving the growing and harvesting process with time and experience. The variations in palatability that were seen commercially from farm to farm cannot be adequately replicated in formal experimentation due to the constraints of experimental method and design.

Measurements during the feeding study in Autumn 3 (Platfoot \& Stevens 2003) highlighted the early live weight and BCS loss for whole-crop silage compared to pasture silage. The low acceptance of the whole-crop cereal silage was overcome by molasses fed to that treatment only at $0.2 \mathrm{~kg} \mathrm{DM} / \mathrm{cow} /$ day for 10 days. However the live weight improved in the last 10 days suggesting BCS could also have improved from that point onwards.

\section{Conclusions}

The autumn results found that feeding whole barley cereal silage in the place of pasture silage at approximately 3 to $5 \mathrm{~kg} \mathrm{DM} /$ cow/day has the potential to increase per cow performance by $0.1 \mathrm{~kg} \mathrm{MS} /$ day in two of the four demonstrations. The effectiveness of whole-crop cereal silage is directly related to the quality of the silage offered.
No significant conclusion can yet be drawn from the spring data. Further studies need to address the responsiveness of cows in spring due to variations in the quantity and quality of pasture offered to the cows.

The nutrient concentrations of whole-crop cereal silage were variable.

Palatability issues with three of the six silages suggest that this is an area of significant concern that may require further research to establish the extent of the problem and the parameters that accompany such problems. Therefore it is important to monitor on farm situations to gauge the extent of palatability problems and/or cow behaviours to understand why this issue exists.

Preliminary analysis suggests that liveweight changes are relatively well predicted by the total amount of energy consumed by the dairy cow, rather than any specific property of whole-crop cereal silage.

\section{ACKNOWLEDGEMENTS}

Thanks go to the farmers and sharemilkers, $\mathrm{W}$ and $\mathrm{J}$ Marshall, H Blom and V van Ectelt, $\mathrm{K}$ and B Thomson, $\mathrm{D}$ and $\mathrm{V}$ Parker, $\mathrm{M}$ and $\mathrm{H}$ Kowalewski, and J Greenslade who donated herds, feed and time to these studies; Chris McLeod for field work at the Lincoln site; MAF Sustainable Farming Fund, the Foundation for Arable Research, the Global Programme of the Dairy Board, and farmers in the SFF project for funding.

\section{REFERENCES}

Corson D.C.; Waghorn, G.C.; Ulyatt, M.J.; Lee, J. 1999. NIRS forage analysis and livestock feeding. Proceedings of the New Zealand Grassland Association 61: 127-132.

de Ruiter J.M.; Hanson, R.; Hay, A.S.; Armstrong, K.W.; Harrison-Kirk, R.D. 2002. Whole-crop cereals for grazing and silage: balancing quality and quantity. Proceedings of the New Zealand Grassland Association 64: 181-189.

Khorasani, G.R.; Okine, E.K.; Kennelly, J.J.; Helm, J.H. 1993. Effect of whole-crop cereal grain silage substituted for alfalfa silage on the performance of lactating dairy cows. Journal of Dairy Science 76: 3536-3546.

Kristensen, V.F. 1992. The production and feeding of whole-crop cereals and legumes in Denmark. pp. 2138. In: Whole-crop cereals. Eds. Stark, B.A; Wilkinson, J.M. Chalcombe Publications, Kent, UK.

Leaver, J.D.; Hill, J. 1992. Feeding cattle on whole-crop cereals. pp. 59-72. In: Whole-crop cereals. Eds. Stark, B.A.; Wilkinson, J.M. Chalcombe Publications, Kent, UK.

National Research Council. 2001. Nutrient requirements of dairy cows. National Academy Press, Washington D.C., USA. 
O’Kiely, P.; Moloney, A.P. 1995. Performance of cattle offered whole-crop barley of wheat silage. Irish Journal of Agricultural and Food Research 34: 1324.

Patterson, H.D.; Thompson, R. 1971. Recovery of inter-block information when block sizes are unequal. Biometrika 58: 545-554.

Phipps, R.H.; Weller, R.F.; Siviter, J.W. 1992. Wholecrop cereals for dairy cows. pp. 51-58. In: Wholecrop cereals. Eds. Stark, B.A.; Wilkinson, J.M. Chalcombe Publications, Kent, UK.
Platfoot, G.; Stevens, D. 2002. Whole cereal crop silage - on-farm feeding demonstrations. Proceedings of the South Island Dairy Event, Invercargill: 153-164.

Platfoot, G.; Stevens, D. 2003. Feeding whole cereal crop silage: A summary of four studies in Otago and Southland. Report to MAF Sustainable Farming Fund. 4 pp.

Tetlow, R.M.; Wilkinson, J.M. 1992. Whole-crop cereals for beef cattle. pp. 73-84. In: Whole-crop cereals. Eds. Stark, B.A.; Wilkinson, J.M. Chalcombe Publications, Kent, UK. 